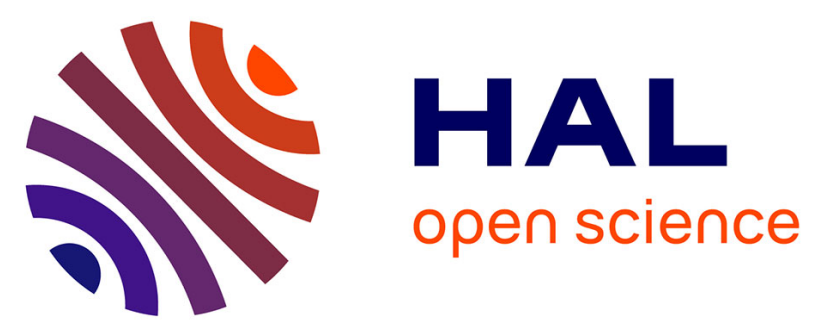

\title{
Compound response of marine and terrestrial ecosystems to varying climate: pre-anthropogenic perspective from bivalve shell growth increments and tree-rings
}

Samuli Helama, Bernd R. Schöne, Andreas J. Kirchhefer, Jan K. Nielsen, David L. Rodland, Ronald Janssen

\section{To cite this version:}

Samuli Helama, Bernd R. Schöne, Andreas J. Kirchhefer, Jan K. Nielsen, David L. Rodland, et al.. Compound response of marine and terrestrial ecosystems to varying climate: pre-anthropogenic perspective from bivalve shell growth increments and tree-rings. Marine Environmental Research, 2007, 63 (3), pp.185. 10.1016/j.marenvres.2006.08.003 . hal-00501886

\section{HAL Id: hal-00501886 \\ https://hal.science/hal-00501886}

Submitted on 13 Jul 2010

HAL is a multi-disciplinary open access archive for the deposit and dissemination of scientific research documents, whether they are published or not. The documents may come from teaching and research institutions in France or abroad, or from public or private research centers.
L'archive ouverte pluridisciplinaire HAL, est destinée au dépôt et à la diffusion de documents scientifiques de niveau recherche, publiés ou non, émanant des établissements d'enseignement et de recherche français ou étrangers, des laboratoires publics ou privés. 


\section{Accepted Manuscript}

Compound response of marine and terrestrial ecosystems to varying climate: pre-anthropogenic perspective from bivalve shell growth increments and treerings

Samuli Helama, Bernd R. Schöne, Andreas J. Kirchhefer, Jan K. Nielsen, David L. Rodland, Ronald Janssen

PII: S0141-1136(06)00176-0

DOI: 10.1016/j.marenvres.2006.08.003

Reference: MERE 3065



To appear in:

Marine Environmental Research

Received Date: 25 February 2006

Revised Date: 2 August 2006

Accepted Date: $\quad 8$ August 2006

Please cite this article as: Helama, S., Schöne, B.R., Kirchhefer, A.J., Nielsen, J.K., Rodland, D.L., Janssen, R., Compound response of marine and terrestrial ecosystems to varying climate: pre-anthropogenic perspective from bivalve shell growth increments and tree-rings, Marine Environmental Research (2006), doi: 10.1016/j.marenvres. 2006.08 .003

This is a PDF file of an unedited manuscript that has been accepted for publication. As a service to our customers we are providing this early version of the manuscript. The manuscript will undergo copyediting, typesetting, and review of the resulting proof before it is published in its final form. Please note that during the production process errors may be discovered which could affect the content, and all legal disclaimers that apply to the journal pertain. 
Compound response of marine and terrestrial ecosystems to varying climate: preanthropogenic perspective from bivalve shell growth increments and tree-rings

Samuli Helama ${ }^{\mathrm{a} *}$, Bernd R. Schöne ${ }^{\mathrm{a}}$, Andreas J. Kirchhefer ${ }^{\mathrm{b}}$, Jan K. Nielsen ${ }^{\mathrm{a}}$, David L. Rodland $^{\mathrm{a}}$, Ronald Janssen ${ }^{\mathrm{c}}$

anstitute for Geology and Palaeontology, Bio-INCREMENTS Research Group, Johann Wolfgang Goethe University, D-60325 Frankfurt am Main, Germany

${ }^{\mathrm{b}}$ Department of Biology, Faculty of Science, University of Troms $\phi$, N-9037 Troms $\phi$, Norway

${ }^{c}$ Forschungsinstitut Senckenberg, Senckenberganlage 25, 60325 Frankfurt am Main, Germany *Corresponding author, currently at: Department of Geology, P.O. Box 64, 00014 University of Helsinki, Finland; e-mail: samuli.helama@helsinki.fi

\begin{abstract}
Annual growth increments from shells of the ocean quahog (Arctica islandica L.) from northwest Norway and from tree-ring samples of the Scots pine (Pinus sylvestris L.) from nearby coastal areas. The reconstructed annual growth increments were used to compare growth variability in marine and terrestrial ecosystems. Spatiotemporal comparison of the growth records showed statistically significant correlation during the 19th century A.D., indicative of ecosystemindependent response to pre-anthropogenic climate variations. Geographical correlation between marine and terrestrial records was only observed at the local scale. Years with particularly low
\end{abstract}


winter or high summer North Atlantic Oscillation (NAO) indices showed the best synchronization of marine and terrestrial growth. Despite strong correlation during historical time, our palaeoecological evidence suggests that marine and terrestrial ecosystems may show dissimilar growth reaction to recently observed positive winter-NAO phases.

Keywords: coastal zone; climate change; palaeoecology; clams; atmospheric motion; sclerochronology; dendrochronology; North Atlantic Oscillation

\section{Introduction}

Records of change in oceanic, atmospheric and terrestrial systems are needed to enhance our understanding about the anthropogenic impact on different biomes. Such records can be either direct observations of environmental phenomena, or reconstructed series from natural archives that work as proxies for direct observations. In order to be comparable with one another, such proxy records must possess sufficient duration, similar temporal resolution and equivalent seasonal expression. Preferably, absolute dating control should be available. Appropriate records may be produced for aquatic and terrestrial ecosystems by means of sclerochronology (Jones 1983) and dendrochronology (Fritts 1976), using growth increment measurements derived from mollusc shells and tree stems, respectively. Sclerochronological and dendrochronological time series can be cross-dated within a given population (Douglass 1941; Fritts 1976; Marchitto et al. 2000; Helama et al. 2006) and can be directly calibrated against instrumental records (Fritts 1962; Fritts et al. 1971; Jones 1981; Jones and Quitmyer 1996), making them ideal proxy archives for such studies. 
Natural variability over large parts of coastal Europe is greatly influenced by the coupled oceanatmosphere system of the North Atlantic. Oceanic circulation transports heat and moisture towards the north, while extratropical atmospheric patterns typically control the transport of airmasses over Western Europe (Hurrell et al. 2001; Wanner et al. 2001; Visbeck 2002). Intensity of heat and moisture transport is not stable, but exhibits notable temporal variability. These changes have great influence on regional ecosystems and society. This is especially the case in Fennoscandia where the climate (Hurrell 1995; Chen and Hellström 1999; Lee et al. 2000; Uvo and Berndtsson 2002) and the flora and fauna (D'Arrigo et al. 1993; Mysterud et al. 2001; Lindholm et al. 2001; Solberg et al. 2002; Post 2003; Macias et al. 2004; Helama et al. 2005) have been shown to vary with the changes attributable to the ocean-atmosphere system of the North Atlantic. Here we examine growth records from marine and terrestrial ecosystems along the coastal areas of northwest Norway by means of sclerochronology and dendrochronology. The focus of the present study is to present and compare the marine growth variability to terrestrial variations during the pre-anthropogenic period, over the first seven decades of the $19^{\text {th }}$ century (A.D.). This 'historical' study period predates the era of anthropogenic climate forcing, and therefore thus provides information about natural climate variability and ecosystem response.

The inter-proxy comparison was accompanied by correlation analysis using environmental data, particularly the record of the North Atlantic Oscillation (Hurrell 1995; Jones et al. 1997), as a predictor. Our goals are (1) to determine if the two proxies show significant common variability, and, if they do, (2) to attempt to link the growth variations with climatic factors. The first issue is 
important because the co-variability suggests that the marine and terrestrial systems may respond to the present and future climate fluctuations in a similar manner. The presence of a common growth signal could also allow absolute dating control of late Holocene marine shells using the local tree-ring series as reference material. The latter issue (2) could reconcile the three constituents of the natural perturbations, atmospheric, marine and terrestrial. This is especially important due to the threat of changing climate, where the NAO may play a significant role (Hurrell et al. 2001; Visbeck 2002).

\section{Material and methods}

\section{Sclerochronological data}

Sclerochronological data were obtained from ocean quahog (Arctica islandica L.) shells. One great benefit of this bivalve species for sclerochronological studies is its longevity; it may reach ontogenetic ages of several centuries (Jones 1980, 1983; Ropes et al. 1984, Schöne et al. 2005a). Four specimens for the present study come from Senckenberg Museum (Senckenberganlage 25, Frankfurt am Main, Germany). Four samples were collected alive in July 1861. The precise site of collection is not known, but the old label reads "Tromsø" (see Fig. 1). Previously, Schöne et al. (2003b) have published the growth records of two of these specimen, but there is a mistake in the map by Schöne et al. (2003b: Fig. 1) since the position of the sampling site is marked hundreds of kilometers too far south in that map. 
Compared to tree-rings, the structure of shell increment appearance is generally much more complex with increments of different order (periodicities by tidal, daily, lunar and annual cycles) of scale. The annual banding of shell growth was examined for this study. Annual periodicity of Arctica islandica shell growth has been studied for independent regions and its character is well known (Thompson et al. 1980; Jones 1980, 1983; Schöne et al. 2005b). In addition, the temporal basis of annual increments coincides with the periodicity of tree-rings and the two types of records thus form potentially suitable counterparts for each other.

Specimens of Arctica islandica were mounted on a plexiglass cube and quick-drying metal epoxy resin (JB KWIK-WELD) was applied to the surface of the valves along the axis of maximum growth. Sections of 2-3 mm thick were cut using Buehler Isomet low-speed saw and mounted on a glass slide, ground and polished on glass plates with $6 \mu \mathrm{m} \mathrm{SiC,} 4 \mu \mathrm{m} \mathrm{SiC} \mathrm{and} 1 \mu \mathrm{m}$ $\mathrm{Al}_{2} \mathrm{O}_{2}$ powder. Polished sections were immersed in a solution of $500 \mathrm{ml} 1 \%$ acetic acid, $500 \mathrm{ml}$ $25 \%$ glutaraldehyde and $5 \mathrm{~g}$ alcian blue powder for 25 minutes at $37-40^{\circ} \mathrm{C}$ (Schöne et al. 2005a, b). Etched sections were rinsed with demineralized water and allowed to air-dry. Increments were viewed under a reflective light binocular microscope and digitized with a Nikon Coolpix ${ }^{\circledR}$ 995 camera. Shell growth increments were identified and their widths measured in the outer shell layer, from umbo to the ventral edge. Widths of the increments were measured from the outer shell layer to the nearest $1 \mu \mathrm{m}$ with $\mathrm{Scion} / \mathrm{NIH}$ version 4.0 .2 beta image software (http://www.scioncorp.com).

\section{Dendrochronological data}


Dendrochronological material, tree-rings of Scots pine (Pinus sylvestris L.), was obtained from 8 different sites in northern Norway (Table 1, Fig. 1). Tree-ring sample cores were extracted from living trees using an increment borer. Cores or cross-sections were also sampled from dead trees and tree remains preserved on dry forest ground. The data of three sites (chronologies 1-3 in Table 1) is part of the WSL-Birmensdorf Tree Ring Data 2000 (Schweingruber 1988; Schweingruber et al. 1991) and this data was obtained from the International Tree-Ring Data Bank (part of the NOAA Paleoclimatology Program and World Data Center for Paleoclimatology) (Grissino-Mayer and Fritts 1997). Five of the sites (chronologies 4-8 in Table 1) were collected previously by Kirchhefer (1999, 2000, 2001), who has provided detailed information about the characteristics of the sites and their growth performance as well as dendroclimatic interpretation. The widths of these rings were measured, from pith to bark, under a visible light microscope in a computer aided system.

\section{Climatic data}

Local climate records from Troms $\varnothing$ begin in 1867 and did not overlap with shell growth records. Instead, sclerochronological and dendrochronological records were compared with the monthly North Atlantic Oscillation (NAO) indices of Jones et al. (1997). The NAO is characterized by an oscillation of atmospheric mass between the Arctic and the subtropical Atlantic. It produces large changes in the mean wind speed and direction over the North Atlantic, which in turn influence the heat and moisture transport between the Atlantic and the continents around it (Hurrell 1995). 
Monthly NAO indices were used here as computed by Jones et al. (1997), that is, from the difference of sea level pressure between Gibraltar and Iceland. The earliest year of this record is 1821. In addition, the monthly temperature mean and precipitation sums from Troms $\emptyset$ were adopted from the dataset of Tuomenvirta et al. (2001) to exemplify the influence of NAO on local climate.

\section{Chronology construction and comparison}

Individual series of tree-rings and shell growth increments exhibit a trend as a function of ontogenetic age of the organisms (Huntington 1914; Fritts 1976; Dunca 1999; Marchitto et al. 2000; Schöne et al. 2005). Such a trend, commonly referred to as a growth trend, is largely due to physiological ageing and three-dimensional sizing of the organism and is therefore targeted for removal prior to the analysis of a common growth signal (e.g., Fritts 1976; Helama et al. 2006). In the present study, growth trends were captured using cubic spline function (Cook and Peters 1981) and removed by dividing the observed annual growth value by the expected growth value of the spline curve. 24-year cubic splines with a 50 percent frequency cut-off were fitted individually to each series of shell growth increments and tree-rings (Fig. 2). This rather 'flexible' growth trend function thus captures the growth variations at multi-decadal time-scales and removes them from resulting growth indices. This growth trend function was a compromise between those slightly more flexible splines that were previously shown to greatly increase the common growth signal between Arctica islandica increment series (Helama et al. 2006) and those more 'rigid' spline curves used previously in the region for dendrochronological purposes 
(Lindholm et al. 1999; Helama et al. 2004). Moreover, it is noteworthy that the use of described spline function, instead of some 'deterministic' growth trend equation, allowed us to use an identical function to model growth trends in both shell growth increment and tree-ring datasets.

Dimensionless ratio-based indices were carefully cross-dated. Variations in tree-rings and shell growth increments were examined separately and synchronized among all available samples from a given site and species. Co-variation between the individual series ensures the dating of each annual growth band, tree-ring or shell increment, to an accuracy of one year, providing absolute dating control of examined characteristics. Cross-dating is a routine procedure of dendrochronological studies (Douglass 1941; Fritts 1976; Wigley et al. 1987); its feasibility and the importance for studies of the periodic shell growth increments were previously demonstrated by Marchitto et al. (2000) and Helama et al. (2006).

Cross-dated index series were averaged into mean time series of species-specific and site-specific chronologies using the arithmetic mean. Statistical estimates of skewness and kurtosis of the mean chronologies implied that the observed annual index values did not violate the assumption of normal distribution. The autocorrelations of the chronologies were in general low and mostly insignificant. The highest level of autocorrelation was observed for the chronology of $A$. islandica (Table 1). The autocorrelation of the series may hamper the assumption of independent observations in estimating the level of statistical significance for Pearson correlations (Yule 1926; Bartlett 1935). Quenouille (1952) provided a formula to estimate the effective number of independent observations $\left(n_{e f f}\right)$ to be used in testing the correlation between two time series 
$n_{\text {eff }} \approx n /\left(1+2 r_{1} r_{1}{ }^{\prime}+2 r_{2} r_{2}{ }^{\prime}+\ldots\right)$

where $n$ is the number of observations and $r_{1}$ and $r_{l}$ ' are the autocorrelations of the first and second time series with a lag 1 (Table 1) and $r_{2}$ and $r_{2}$ ' are the autocorrelations of the two time series with a lag 2 and so on. With regards to present sample, inclusion of autocorrelations with lag-1 and lag- 2 is adequate. In serially correlated time series $n_{\text {eff }}$ thus reduces in proportion to the level of autocorrelation. The treatment of Quenouille (1952) was performed prior to comparison of A. islandica and Pinus sylvestris chronologies and the significance level for the association was estimated according to $n_{\text {eff }}$ instead of $n$.

\section{Results and discussion}

Spatiotemporal inter-species comparison

After growth trends were removed and the series cross-dated, the correlation between the Arctica islandica index series was 0.330 . This result compared well with the similarly detrended and correlated tree-ring chronologies (Table 1). Correlation between the sample series indicated similar growth response to similar external forcings. This suggests that individuals of $A$. islandica probably experienced similar environmental conditions during their life span. Moreover, this would suggest that the shells were collected, if not in a single site, at least from locations nearby to each other. Even more importantly, the obtained common growth signal between the individual shell growth increment index series signified the possibility of averaging 
the series into one mean sclerochronology.

Shell increment chronology had the sample size of two or greater between the years 1806 and 1861 and the series could thus be cross-dated over this interval only. Consequently, this was the study period for further growth comparisons.

Correlations between the sclerochronology and different dendrochronologies were evidently highest when computed with the tree-ring data derived from the area near Troms $\emptyset$ (Fig. 3). Since the spatial correlation of climatic phenomena are supposed to decline with longer distances, the similar trend in inter-species correlations could therefore confirm the earlier assumption about the approximate location of sample collection (around Troms $\varnothing$ ). Unfortunately, the spatial resolution of tree-ring network did not allow more detailed determination.

The mean correlation between the tree-ring chronologies, over the study period 1806-1861, was 0.421. Correlativity of the tree-ring site chronologies was high enough to support the construction of one regional chronology. As exemplified in Fig. 3, the similarity of growth patterns in shell increments and tree-rings was due to proximity of the sites; inter-species correlations over longer distances were clearly lower than correlations with nearby sites and correlations close to zero were observed when distances exceeded $100 \mathrm{~km}$. A new regional dendrochronology was averaged using the tree-ring series from local site chronology candidates (Fig. 3). This tree-ring chronology was then compared with sclerochronology of A. islandica. Accounting for autocorrelation of the sclerochronology (for which the autocorrelation was higher than tree-rings), we detect significant inter-species correlation (Fig. 4) over the available period 
indicating that the two ecosystems shared common growth variations significantly more than what could be statistically expected by pure chance. The Durbin-Watson (1951) $d$-test showed that no statistically significant serial correlation was present $(0.01$ level $)$ in the residuals from this regression (Fig. 4b).

\section{Climatic interpretation}

Significant correlation is observed between growth records derived from the studied marine and terrestrial archives (Fig. 4). Climate has previously shown to synchronize population variability among different species over considerable distances (e.g. Post and Forchhammer 2002) and the described synchrony in inter-species growth dynamics (Fig. 4) is best viewed in the context of climate variability. One particular climatic factor liable to cause growth correlation is summer temperatures. The radial growth of Pinus sylvestris is known to benefit especially from warm summer temperatures in the study region (Kirchhefer 1999, 2000, 2001). The growth of Arctica islandica has previously shown to depend on growing season temperatures and food availability (Witbaard 1996; Marchitto et al. 2000; Witbaard et al. 2003; Schöne et al. 2003a, 2005). Although the growth response of Arctica islandica has not yet been thoroughly studied in the region, these two factors could likewise be assumed to bear significant influence on the growth of the species also here. Fluctuating summer temperatures could thus act as driving force behind the described synchrony of the growth records. It is not however clear how strongly air temperatures are related to the benthic environmental conditions experienced by these bivalves, and there may be some complementary factors explaining the co-variability. 
In the North Atlantic, the heat that the ocean gains at low latitudes is carried northward within the Gulf Stream and transferred into the atmosphere by conduction and evaporation. This heat is typically transported over coastal Europe due to atmospheric patterns, ascribed to the North Atlantic Oscillation-index (NAO-index; Hurrell 1995; Jones et al. 1997). According to Hurrell (1995), December through March NAO-index correlates strongly with precipitation of the same season along the Norwegian coast facing towards the North Atlantic Ocean, with coefficients 0.77 and 0.66 in Bergen and Stavanger, respectively. These towns are situated further south than Troms $\varnothing$, but the NAO bears some influence on the climate of the study region. There is an especially clear NAO-climate connection to temperatures in the study region (Table 2). However, as previously noted by Chen \& Hellström (1999) in Sweden, the strength of the NAO-climate association varies regionally and through time. This implies that also the relationships between the NAO and ecosystems are expected to vary as a function of time.

Interestingly, both marine and terrestrial ecosystems have previously been demonstrated to show NAO-dependent behaviour in the study region. According to Schöne et al. (2003b), the longperiod shell increment variability ('low-pass' filtered growth records, see details in Schöne et al. $2003 b$ ) of A. islandica show correlation with winter-NAO-index from the central North Sea up to the coastal Norwegian Sea and in the study region. With regard to forest ecosystems, Macias et al. (2004) studied the dependence of Pinus sylvestris tree-ring widths on the NAO in northern Norway and Finland since the year 1880. They showed that while the influence of NAO on treerings was evident, it exhibited temporal and seasonal instability. More precisely, it was shown that the correlations between the NAO-indices and tree-rings varied markedly according to the 
sign of the NAO-phase (Macias et al. 2004).

Influence of North Atlantic Oscillation (NAO)

In order to test the hypothesis of NAO-related inter-species growth synchrony with our data, we performed a comparison between the sclerochronology, dendrochronology and NAO-indices (Jones et al. 1997). The potential influence of NAO was studied over the temporal overlap between records during the period 1821-1861. Based on the previous studies and localized correlations (Table 2), the influence of NAO on climate was expected to have strongest impact during the winter (December through March). This is the NAO-season frequently discussed in the literature (for review, see Hurrell et al. 2001, 2003; Wanner et al. 2001) due to its significant influence on natural systems. Although the activity of the organisms during the winter is reduced, winter climate may influence subsequent growth, although the proxy archive lags behind. At high latitudes, snow brings inertia for the climate system and the winter climate should not be neglected when studying the climatic sensitivity of organisms (e.g. Vaganov et al. 1999). We therefore chose to compare the sclerochronological and dendrochronological records with winterNAO (December to March). The mid-summer (July) NAO-season was also tested, as this is the season in which temperatures are liable to be of greatest importance on the growth variability in our marine and terrestrial settings.

As previously mentioned, the influence of NAO on ecosystems may be different during the years of positive to negative NAO-phases in the study region (Macias et al. 2004). Therefore, we estimated the inter-proxy correlations as a function of the NAO-index gradient (Fig. 5). That is, 
the annual bivalve and tree growth values were re-aligned according to the NAO-index of each year (in re-aligned series the first and last growth observations were thus associated with the most positive and the most negative NAO-indices, respectively). Re-alignment was performed separately according to winter-NAO-index and mid-summer-NAO-index. The series of correlations using the 20-point window were then calculated in the resulting NAO-domain by sliding the correlation window along the re-aligned time series by one point steps. Correlation coefficient was calculated for each position of the window. The results are shown separately for winter-NAO and mid-summer-NAO (Fig. 5).

Growth synchrony seemed to increase with very positive and decrease with negative midsummer-NAO-indices (Fig. 5). As the temperatures in the study region were positively correlated with NAO-index (Table 2), the obtained results could indicate that especially the years with warm summers may experience increased growth synchrony between the two records. By contrast, growth synchrony seemed to increase with very negative and decrease with positive winter-NAO-indices (Fig. 5). While Fig. 5 depicts the correlations calculated using 20-point windows, we obtain the correlations 0.937 and -0.545 for the most negative and positive 5-point ends of the winter-NAO-gradient. While these correlations are consistent with the gradient by 20-point correlations (Fig. 5), they also indicate that the influence of the extreme NAO-years is probably even amplified by the most anomalous NAO-phenomena. Since the activity of the organisms is reduced in winter, the interpretation of the growth synchrony due to negative winter-NAO phases probably requires an intra-annually lagged (from winter to spring) physical model, through the local NAO-climate correlations (Table 2). 
Climate affects the marine ecosystems indirectly by changing the ecosystem properties that are of importance to the growth of organisms (Ottersen et al. 2001, 2004); significant aquatic properties for the growth of marine organisms include temperature, salinity, food supply, water column stratification and sedimentation (Schöne et al. 2003a; Witbaard et al. 2003). Growth may be influenced contemporaneously or with lagged responses (Witbaard et al. 2003; Ottersen et al. 2001, 2004). The influence of winter-NAO on bivalve growth could be due to intra-annually lagged responses. Snow conditions (depending on both snowfall and winter temperatures, in turn influenced by NAO, see Table 2) in the adjacent land areas may affect spring floods and thus seasonal sedimentation rates with cascading influence on the food supply of marine organisms in coastal waters. Positive growth influence could be derived from increased food supply, but sediment influx may also influence the growth of these organisms negatively, and the potential for non-linear relationship cannot be excluded. With regard to tree growth, the relationship may be more direct, due to thawing and freezing of the soil, as suggested by Kirchhefer (1999). The insulating effect of snow on the root system is known to bear positive influence on the growth and vitality of northern pines (Jalkanen 1993). As parallel evidence, the radial growth of Pinus sylvestris has been shown to correlate significantly and positively with mid-winter precipitation and temperature in the study region during the era of local instrumental weather observations (Kirchhefer 2000).

\section{Conclusions}

Despite their completely different growing environment as well as distinct physiological and 
ecological separation, Arctica islandica and Pinus sylvestris showed significantly similar growth variability during the studied interval. It would be difficult to explain the correlated growth patterns by means other than climate. We have identified factors that serve as potential predictors linking the two proxy records: summer temperatures and the North Atlantic Oscillation (NAO). Increasing synchronization occurs between inter-species growth records in association with years of negative winter-NAO-index and years of positive mid-summer-NAO-index. This correlation indicates potentially non-linear connection of the ocean-atmosphere system with marine and terrestrial ecosystems. During the recent decades, winter-NAO has experienced a pervasive positive phase (Hurrell et al. 2001) and its influence on the marine and terrestrial ecosystems should be intensively studied. During the years of positive winter-NAO-index, the two ecosystems did not correlate positively. Our palaeoecological evidence thus suggests that the two ecosystems may be showing dissimilar growth reaction to this recent positive NAO phase.

Our spatial analysis confirmed the conceivable geographical origin of the museum shell specimens. This was done with the spatial comparison of sclerochronology with a network of tree-ring chronologies along the coastal areas. Our results implied that a multi-proxy analysis using sclerochronlogical and dendrochronological series could also be useful to resolve the absolute temporal placement of undated shells by inter-species cross-dating (Fritts 1976). That is to propose that already constructed tree-ring records could potentially be used as master chronologies for nearby collected late Holocene shell material, from archaeological and geological archives (Nielsen et al. 2004) and museum collections. 


\section{Acknowledgements}

Part of the tree-ring material used here was due to downloadable data of NOAA paleoclimatology at http://www.ngdc.noaa.gov/paleo. We acknowledge Prof. Fritz H. Schweingruber as contributor of this data. The distances between the sites were estimated using an online JavaScript by John A. Byers. We are grateful to the three anonymous referees for their comments on the earlier version of the manuscript, which considerably improved the final presentation. The work of $\mathrm{SH}$ was made possible by a postdoctoral scholarship from the Foundation of Koneen Säätiö. The work of BRS was supported by a German Research Foundation (DFG) grant within the framework of the Emmy Noether Program (SCHO 793/1). The work of JKN was made possible by a postdoctoral scholarship (No. 04-0256/20) from the Carlsberg Foundation and the work of DLR by a postdoctoral scholarship from the Alexander von Humboldt Foundation.

\section{References}

Bartlett, M.S. (1935). Some aspects of the time-correlation problem in regard to tests of significance. Journal of the Royal Statistical Society, 98, 536-543.

Chen, D., \& Hellström, C. (1999). The influence of the North Atlantic Oscillation on the regional temperature variability in Sweden: spatial and temporal variations. Tellus, 51A, 505-516. 
Cook, E.R., \& Peters, K. (1981). The smoothing spline: A new approach to standardizing forest interior tree-ring width series for dendroclimatic studies. Tree-Ring Bulletin, 41, 45-53.

D'Arrigo, R.D., Cook, E.R., Jacoby, G.C., \& Briffa, K.R. (1993). NAO and sea surface temperature signatures in tree-ring records from the North Atlantic sector. Quaternary Science Reviews, 12, 431-440.

Douglass, A.E. (1941). Crossdating in dendrochronology. Journal of Forestry, 39, 825-831.

Dunca, E. (1999). Bivalve shells as archives for changes in water environment. Vatten, 55, 279290.

Durbin, J. \& Watson, G.S. (1951). Testing for serial correlation in least squares regression II. Biometrika, 38, 159-178.

Fritts, H.C. (1962). An Approach to Dendroclimatology: Screening by Means of Multiple Regression Techniques. Journal of Geophysical Research, 67, 1413-1420.

Fritts, H.C. (1976). Tree-Rings and Climate (pp. 576). London: Academic Press.

Fritts, H.C., Blasing, T.J., Hayden, B.P., \& Kutzbach, J.E. (1971). Multivariate techniques for Specifying Tree-Growth and Climate Relationships and for Reconstructing Anomalies in Paleoclimate. Journal of Applied Meteorology, 10, 845-864. 
Grissino-Mayer, H.D., \& Fritts, H.C. (1997). The international tree-ring data bank: an enhanced global database serving the global scientific community. The Holocene, 7, 235-238.

Helama, S., Lindholm, M., Meriläinen, J., Timonen, M., \& Eronen, M. (2005). Multicentennial ring-width chronologies of Scots pine along north-south gradient across Finland. Tree-Ring Research, 61, 21-32.

Helama, S., Lindholm, M., Timonen, M., \& Eronen, M. (2004). Detection of climate signal in dendrochronological data analysis: a comparison of tree-ring standardization methods. Theoretical and Applied Climatology, 79, 239-254.

Helama, S., Schöne, B.R., Black, B.A., \& Dunca, E. (2006). Constructing long-term proxy series for aquatic environments with absolute dating control using a sclerochronological approach: introduction and advanced applications. Marine and Freshwater Research, 56 (7), (in press).

Huntington, E. (1914). The Climatic Factor as Illustrated in Arid America (pp. 341). Carnegie Institution Publication 192. Washington: Carnegie Institution of Washington.

Hurrell, J.W. (1995). Decadal Trends in the North Atlantic Oscillation: Regional Temperatures and Precipitation. Science, 269, 676-679.

Hurrell, J.W., Kushnir, Y., \& Visbeck, M. (2001). The North Atlantic Oscillation. Science, 291, 
603-604.

Hurrell, J.W., Kushnir, Y., Ottersen, G., \& Visbeck, M. (2003). An Overview of the North Atlantic Oscillation. Geophysical Monograph, 134, 1-35.

Jalkanen, R. (1993). Defoliation of pines caused by injury to roots resulting from low temperatures. The Finnish Forest Research Institute. Research Papers, 451, 77-88.

Jones, D.S. (1980). Annual cycle of shell growth increment formation in two continental shelf bivalves and its paleoecologic significance. Paleobiology, 6, 331-340.

Jones, D.S. (1981). Annual growth increments in shells of Spisula solidissima record marine temperature variability. Science, $211,165-167$.

Jones, D.S. (1983). Sclerochronology: Reading the Record of the Molluscan Shell. American Scientist, 71, 384-391.

Jones, D.S., \& Quitmyer, I.R. (1996). Marking time with bivalve shells: oxygen isotopes and season of annual increment formation. Palaios, 11, 340-346.

Jones, P.D., Jónsson, T., \& Wheeler, D. (1997). Extension to the North Atlantic Oscillation using early instrumental pressure observations from Gibraltar and South-West Iceland. International Journal of Climatology, 17, 1433-1450. 
Kirchhefer, A.J. (1999). Pine growth and climate AD 1800-1992 along a transect across the Scandes at $69^{\circ}$ N. In: A. J. Kirchhefer, Dendroclimatology on Scots pine (Pinus sylvestris L.) in northern Norway. Doctoral dissertation. Department of Biology. University of Troms $\emptyset$.

Kirchhefer, A.J. (2000). The influence of slope aspect on radial increment of Pinus sylvestris L. in northern Norway and its implications for climate reconstruction. Dendrochronologia, 18, 27 40.

Kirchhefer, A.J. (2001). Reconstruction of summer temperature from tree-rings of Scots pine (Pinus sylvestris L.) in coastal northern Norway. The Holocene, 11, 41-52.

Lee, S.E., Press, M.C., \& Lee, J.A. (2000). Observed climate variations during the last 100 years in Lapland, northern Finland. International Journal of Climatology, 20, 329-346.

Lindholm, M., Eggertsson, Ó., Lovelius, N., Raspopov, O., Shumilov, O., \& Läänelaid, A. (2001). Growth indices of North European Scots pine record the seasonal North Atlantic Oscillation. Boreal Environmental Research, 6, 275-284.

Lindholm, M., Eronen, M., Timonen, M., \& Meriläinen, J. (1999). A ring-width chronology of Scots pine for northern Lapland covering the last two millenia. Annales Botanici Fennici, 36, $119-126$. 
Macias, M., Timonen, M., Kirchhefer, A.J., Lindholm, M., Eronen, M., \& Gutiérrez, E. (2004). Growth Variability of Scots Pine (Pinus sylvestris) along a West-East Gradient across Northern Fennoscandia: A Dendroclimatic Approach. Arctic, Antarctic, and Alpine Research, 36, 565-574.

Marchitto, T.M., Jones, D.S., Goodfriend, G.A., \& Weidman, C.R. (2000). Precise temporal correlation of Holocene mollusk shells using sclerochronology. Quaternary Research, 53, 236246.

Mutvei, H., Dunca, E., Timm, H., \& Slepukhina, T. (1996). Structure and growth rates of bivalve shells as indicators of environmental changes and pollution. Bulletin de l'Institut océanographique, Monaco, $\mathrm{n}^{\circ}$ special, 14, 65-72.

Mysterud, A., Stenseth, N.C., Yoccoz, N.G., Langvatn, R., \& Steinheim, G. (2001). Nonlinear effects of large-scale climatic variability on wild and domestic herbivores. Nature, 410, 10961099.

Nielsen, Jan K., Hanken, N.-M., \& Nielsen, Jesper K. (2004). The relationships between early diagenetic calcite concretions and shell dissolution in subaerially exposed Holocene marine sediments, North Norway. 32nd International Geological Congress, Florence Aug. 20-28, 2004, p. 166.

Ottersen, G., Planque, B., Belgrano, A., Post, E., Reid, P.C., \& Stenseth, N.C. (2001). Ecological effects of the North Atlantic Oscillation. Oecologia, 128, 1-14. 
Ottersen, G., Stenseth, N.C., \& Hurrell, J.W. (2004). Climatic fluctuations and marine systems: a general introduction to the ecological effects. In: N. Stenseth, G. Ottersen, J.W. Hurrell, \& A. Belgrano (eds), Marine Ecosystems and Climate Variation. The North Atlantic. A Comparative Perspective (pp. 3-14). Oxford University Press.

Post, E. (2003). Large-scale climate synchronizes the timing of flowering by multiple species. Ecology, 84, 277-281.

Post, E., \& Forchhammer, M.C. (2002). Synchronization of animal population dynamics by large-scale climate. Nature, 420,168-171.

Quenouille, M.H. (1952). Associated measurements (pp. 242). London: Butterworths Scientific Publications.

Ropes, J.W., Jones, D.S., Murawski, S.A., Serchuk, F.M., \& Jearld, A. (1984). Documentation of annual growth lines in ocean quahogs, Arctica islandica (Linné). Fishery Bulletin, 82, 1-19.

Schöne, B.R., Fiebig, J., Pfeiffer, M., Gleß, R., Hickson, J., Johnson, A.L.A., Dreyer, W., \& Oschmann, W. (2005a). Climate records from a bivalved Methuselah (Arctica islandica, Mollusca; Iceland). Palaeogeography, Palaeoclimatology, Palaeoecology, 228, 130-148.

Schöne, B.R., Houk, S.D., Freyre Castro, A.D., Fiebig, J., Oschmann, W., Kröncke, I., Dreyer, 
W., \& Gosselck, F. (2005b). Daily Growth Rates in Shells of Arctica islandica: Assessing Subseasonal Environmental Controls on a Long-lived Bivalve Mollusk. Palaios, 20, 78-92.

Schöne, B.R., Kröncke, I., Houk, S.D., Freyre Castro, A.D., \& Oschmann, W. (2003a). The cornucopia of chilly winters: ocean quahog (Arctica islandica L., Mollusca) master chronology reveals bottom water temperature and food availability. Senckenbergiana Maritima, 32, 165-175.

Schöne, B.R., Oschmann, W., Rössler, J., Freyre Castro, A.D., Houk, S.D., Kröncke, I., Dreyer, W., Janssen, R., Rumohr, H., \& Dunca, E. (2003b). North Atlantic Oscillation dynamics recorded in shells of a long-lived bivalve mollusk. Geology, 31, 1237-1240.

Schweingruber, F. H. (1988). Tree Rings. Basics and Applications of Dendrochronology (pp. 276). Dordrecht: Kluwer Academic Publishers.

Schweingruber, F.H., Briffa, K.R. \& Jones, P.D. (1991). Yearly maps of summer temperatures in western Europe from A.D.1750 to 1975 and western North America from 1600 to 1982.

Vegetatio 92, 5-71

Solberg, B., Hofgaard, A., \& Hytteborn, H. (2002). Shifts in radial growth responses of coastal Picea abies induced by climatic change during the 20th century, Central Norway. Écoscience, 9, 79-88.

Thompson, I., Jones, D.S., \& Dreibelbis, D. (1980). Annual internal growth banding and life 
history of the ocean quahog Arctica islandica (Mollusca: Bivalvia). Marine Biology, 57, 25-34.

Tuomenvirta, H., Drebs, A., Førland, E., Tveito, O.E., Alexandersson, H., Laursen, E.V., \& Jónsson, T. (2001). Nordklim data set 1.0 - description and illustrations. DNMI klima 08/01. 27 pp.

Uvo, C.B., \& Berndtsson, R. (2002). North Atlantic Oscillation; a Climatic Indicator to Predict Hydropower Availability in Scandinavia. Nordic Hydrology, 33, 415-424.

Vaganov, E.A., Hughes, M.K., Kirdyanov, A.V., Schweingruber, F.H., \& Silkin, P.P. (1999).

Influence of snowfall and melt timing on tree growth in subarctic Eurasia. Nature, 400, 149-151.

Visbeck, M. (2002). The Ocean's Role in Atlantic Climate Variability. Science, 297, 2223-2224.

Wanner, H., Brönnimann, S., Casty, C., Gyalistras, D., Luterbacher, J., Schmutz, C., Stephenson, D., \& Xoplaki, E. (2001). The North Atlantic Oscillations - concepts and studies. Surveys in Geophysics, 22, 321-382.

Wigley, T.M.L., Jones, P.D., \& Briffa, K.R. (1987). Cross-dating methods in dendrochronology. Journal of Archaeological Science, 14, 51-64.

Witbaard, R. (1996). Growth variations in Arctica islandica L. (Mollusca): a reflection of hydrography-related food supply. Journal of Marine Science, 53, 981-987. 
Witbaard, R., Jansma, E., \& Sass Klaassen, U. (2003). Copepods link quahog to climate. Journal of Sea Research, 50, 77-83.

Yule, G.U. (1926). Why do we sometimes get nonsense-correlations between time-series? - A study in sampling and the nature of time-series. Journal of the Royal Statistical Society, 89, 1-64. 


\section{Tables}

Table 1. Tree-ring (Pinus sylvestris) chronologies (No. 1-8) and shell growth (Arctica islandica) increment chronologies (No. 9) used in the present study with the name of the locality (Name), abbreviation of the chronology (Abbr), first year of the chronology (Year F), last year of the chronology (Year L), total number of the individual series in the chronology (sample size, SS1) and the number of series overlapping with the cross-dated part of the sclerochronology (between the years 1806 and 1861; SS2). Other statistics include skewness (Skew) and kurtosis (Kurt), the correlation between the individual series within each chronology (r) and the first order autocorrelation $\left(\mathrm{r}_{1}\right)$. All these four statistics were calculated over the common period 1806-1861. For the locations of the sample sites, see Fig. 1.

\begin{tabular}{c|lccccccccc} 
No. & NAME & Abbr & Year F & Year L & SS1 & SS2 & Skew & Kurt & $r$ & $r_{1}$ \\
\hline 1 & Skibotn & SKI & 1775 & 1978 & 27 & 22 & -0.144 & -0.764 & 0.576 & 0.473 \\
2 & Lofoten & LOF & 1619 & 1978 & 6 & 5 & 0.400 & 0.789 & 0.447 & 0.226 \\
3 & Narvik & NAR & 1702 & 1978 & 29 & 13 & 0.017 & 0.361 & 0.212 & 0.278 \\
4 & Vikran & VIK & 1599 & 1992 & 44 & 43 & -0.033 & 0.193 & 0.348 & 0.259 \\
5 & Addjet & ADD & 1579 & 1992 & 33 & 27 & -0.039 & 0.114 & 0.445 & 0.213 \\
6 & Tauskjerring & TAU & 1545 & 1994 & 32 & 27 & -0.211 & -0.465 & 0.454 & 0.362 \\
7 & Stonglandseidet & STO & 1403 & 1997 & 66 & 51 & -0.289 & -0.207 & 0.314 & 0.211 \\
8 & Nordreisa & LUV & 1515 & 1995 & 68 & 65 & -0.601 & 0.576 & 0.448 & 0.241 \\
9 & Arctica islandica & AI & 1758 & 1861 & 4 & 4 & 0.099 & -0.763 & 0.330 & 0.481
\end{tabular}


Table 2. Pearson correlations $(\times 100)$ between monthly North Atlantic Oscillation $(\mathrm{NAO})$-index and monthly mean temperatures (T) and precipitation sums (P) in Troms $\emptyset$ meteorological station shown separately for the first and second halves of the $20^{\text {th }}$ century. Positive NAOcorrelations with temperature and precipitation imply that enhanced NAO-phase brings warm and moisture weather, respectively. Statistically significant $(\mathrm{p}<0.05)$ correlations are underlined.

\begin{tabular}{l|cccccccccccc} 
Climate $\backslash$ Month & $\mathrm{J}$ & $\mathrm{F}$ & $\mathrm{M}$ & $\mathrm{A}$ & $\mathrm{M}$ & $\mathrm{J}$ & $\mathrm{J}$ & $\mathrm{A}$ & $\mathrm{S}$ & $\mathrm{O}$ & $\mathrm{N}$ & $\mathrm{D}$ \\
\hline $\mathrm{T}(1900-1949)$ & $\underline{40}$ & $\underline{50}$ & $\underline{53}$ & $\underline{29}$ & $\underline{31}$ & $\underline{32}$ & 15 & 2 & $\underline{43}$ & 17 & $\underline{48}$ & 20 \\
$\mathrm{~T}(1950-1999)$ & $\underline{33}$ & $\underline{45}$ & $\underline{30}$ & 25 & $\underline{29}$ & 3 & $\underline{33}$ & $\underline{29}$ & $\underline{28}$ & $\underline{43}$ & 19 & $\underline{28}$ \\
$\mathrm{P}(1900-1949)$ & -9 & 1 & 9 & 11 & -7 & 20 & 22 & -12 & $\underline{-35}$ & -24 & $\underline{-30}$ & -9 \\
$\mathrm{P}(1950-1999)$ & -7 & 6 & 12 & $\underline{-39}$ & -14 & $\underline{37}$ & -9 & -12 & -22 & -10 & -15 & -12
\end{tabular}




\section{Figure captions}

Figure 1. Map showing the tree-ring sampling sites (circles) and the assumed location of the historical shell collection site (triangle). Modified after Kirchhefer (2001). See Table 1 for treering site abbreviations and details.

Figure 2. Determining the growth curve for annual shell growth increments (Arctica islandica) (a) and tree-ring (Pinus sylvestris) widths (b). Growth curve (thick gray line) was fitted to initial growth measurements (thin black line) using 24-year cubic spline function.

Figure 3. Spatial comparison of inter-species growth synchrony: correlations between the sclerochronology and dendrochronologies are highest for the tree-ring sites in the proximity of the Troms $\varnothing$. Tree-ring (Pinus sylvestris) chronologies chosen to represent the growth comparable to local shell growth (Arctica islandica) are shown with filled circles, see Table 1 and Fig. 1 for details about these chronologies.

Figure 4. Correlation (r) between the annual shell growth increments (Arctica islandica) and treering widths (Pinus sylvestris) (a). The relationship between the shell and tree growth shown with linear regression (b).

Figure 5. Correlation between the shell increments (Arctica islandica) and tree-rings (Pinus sylvestris) shown as a function of the (a) magnitude and sign of DJFM (December to March, previous winter to growing season) North Atlantic Oscillation (NAO) indices and (b) mid- 
summer (July, concurrent to growth) -NAO indices. Vertical axis indicates the correlation coefficient that occurred between the upper (upper horizontal axis) and lower (lower horizontal axis) limit of a particular range of NAO-index. 


\section{ACCEPTED MANUSCRIPT}

Fig 1

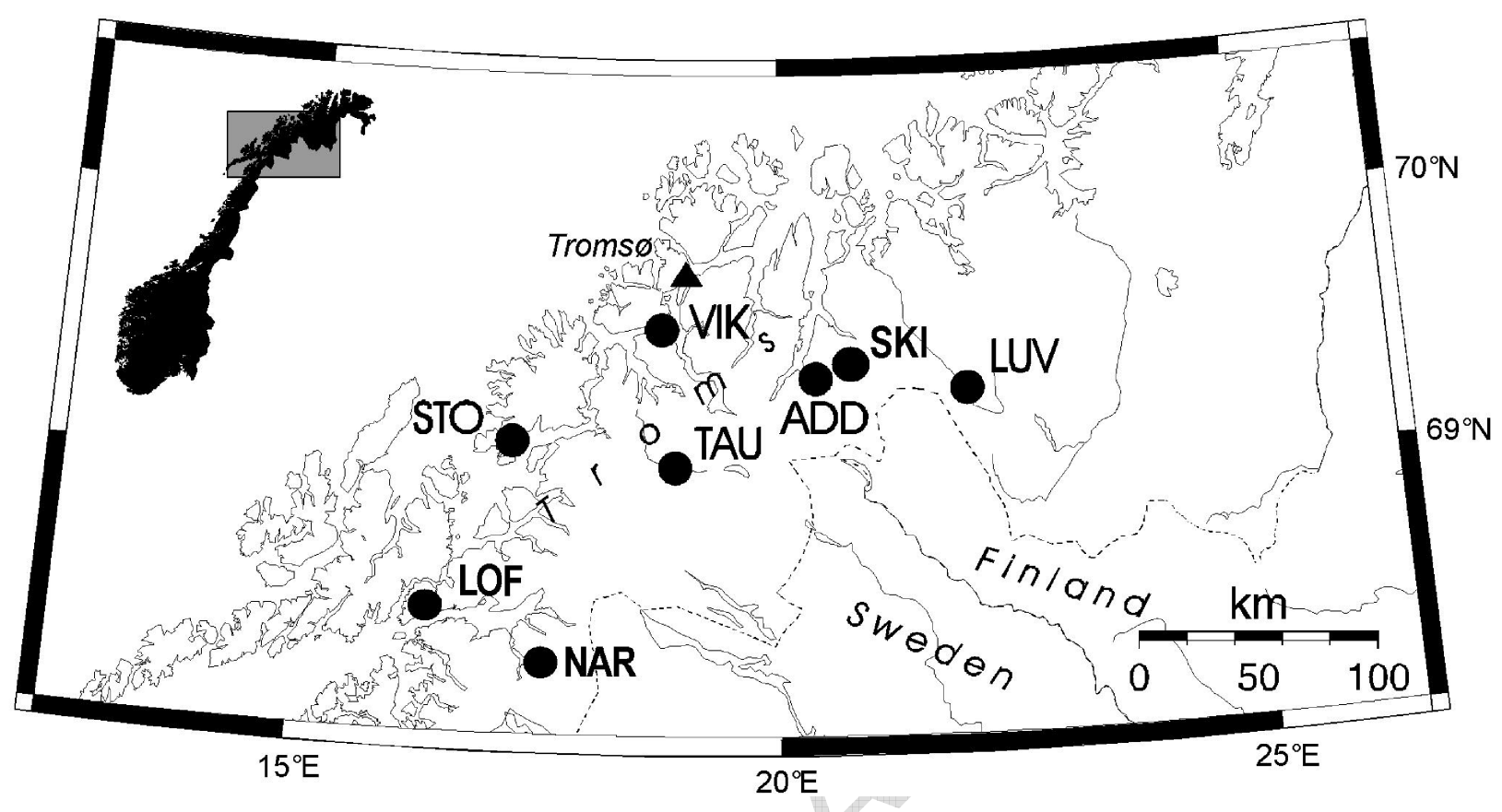




\section{Figure 2}

Fig. 3

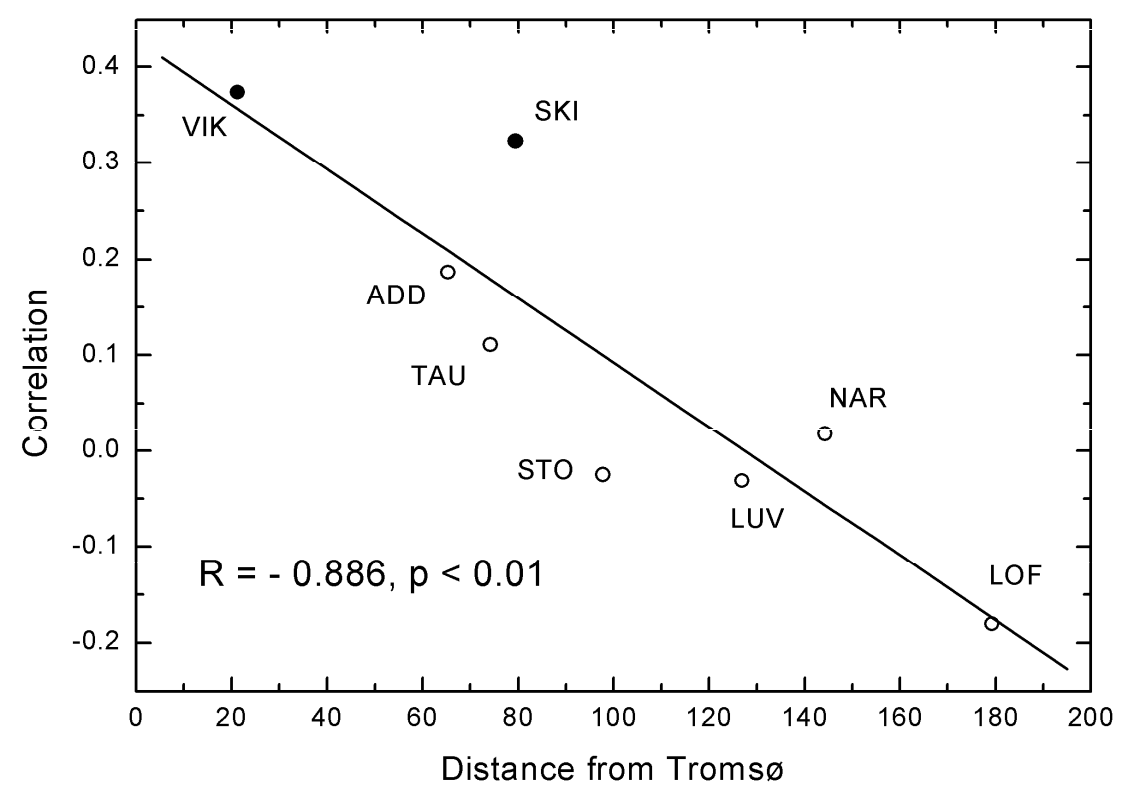


Figure 4
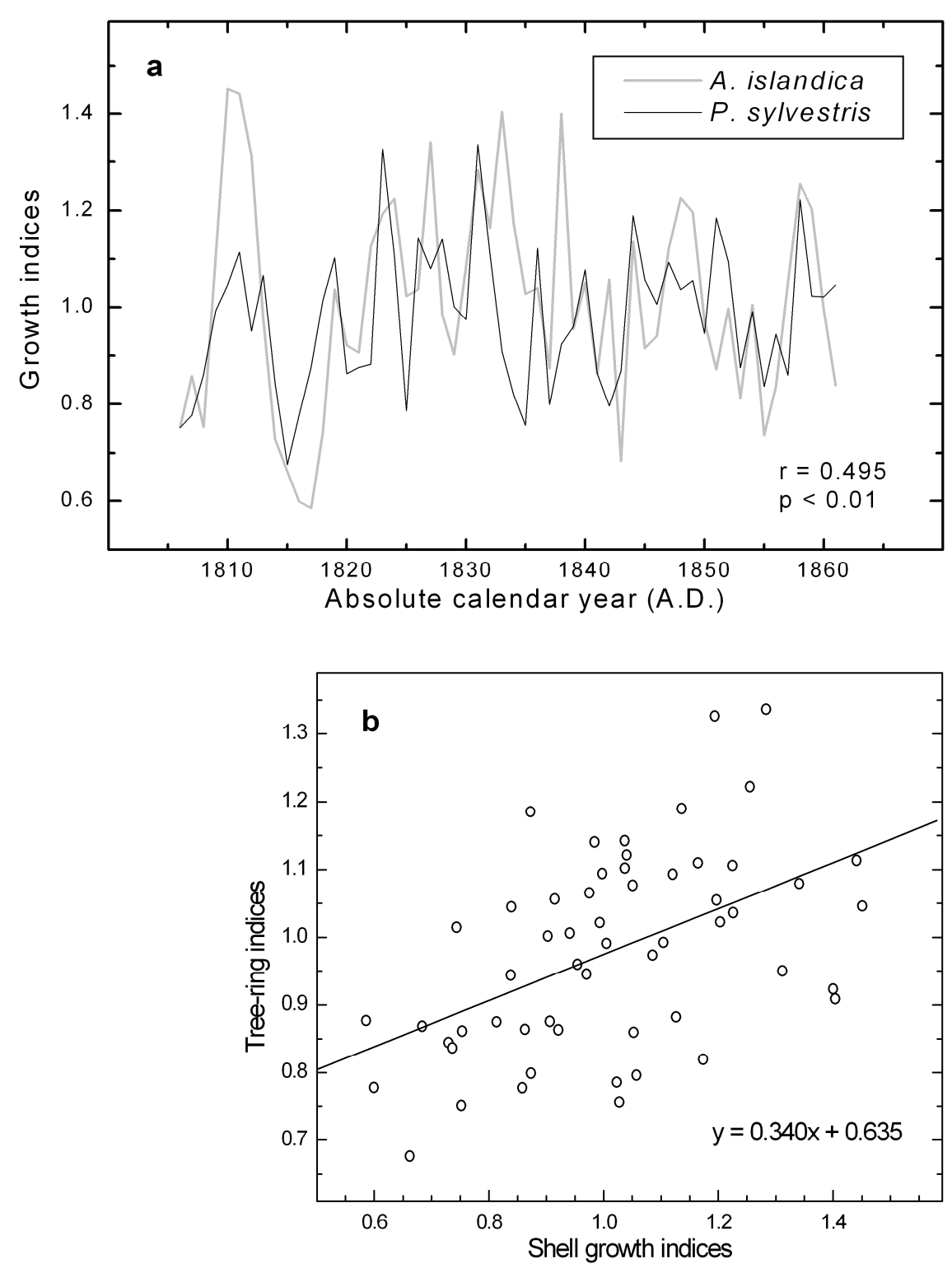


\section{Figure 5}

Winter-NAO-index below
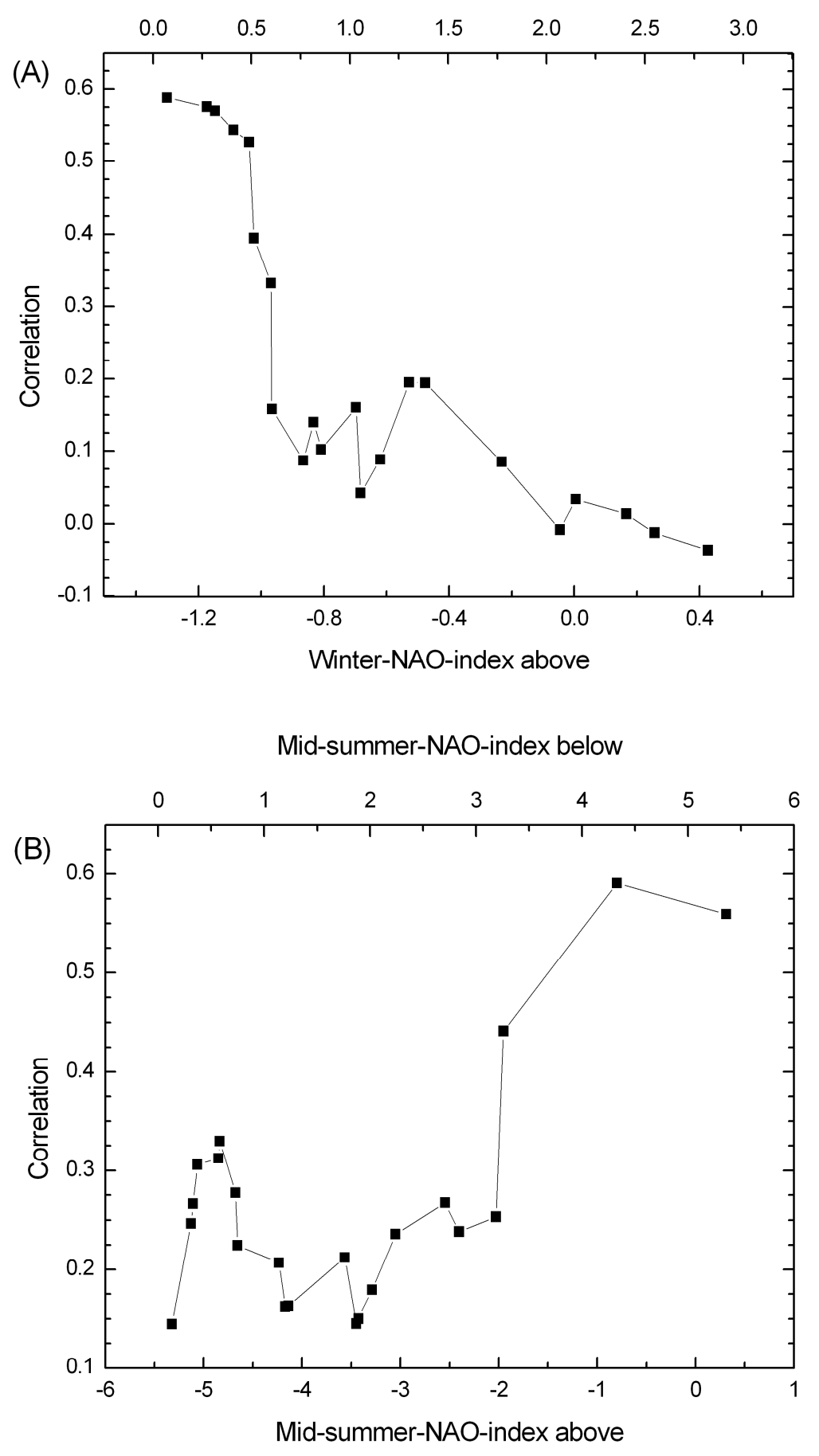